\title{
Зміни балансу поліамінів у процесі розвитку пухлинного процесу в експерименті та клініці
}

\author{
Інститут експериментальної патології, онкології і радіобіологї̈ ім. Р.С. Кавецького НАН Украӥни, Київ \\ Отримано 15.08.2019 \\ Підиисано до друку 70.10.2019 \\ DOI: 10.32471 clinicaloncology.2663-466X.40.23098
}

\begin{abstract}
Вступ. Інгібітори ферментів біосинтезу та інтерконверсії поліамінів (ПА) відомі як одна з груп ефективних протипухлинних засобів. Однак реальні умови рівноваги ферментативних реакцій в системі метаболізму ПА в процесі розвитку пухлин на сьогодні недостатньо вивчені. Кінцевим проявом цього ферментативного балансу виступає патерн спектра ПА в пухлинній тканині та в біологічних рідинах організму. Мета дослідження. Порівняти варіабельність патернів спектра ПА в процесі розвитку пухлин різної етіології та локалізації в експерименті та клініці. Методи дослідження. Патерни спектра ПА вивчали в процесі 3 видів експериментального хімічного канцерогенезу (N-нітрозодіетиламінового гепатоканцерогенезу; 1,2-диметилгідразинового канцерогенезу товстого й тонкого кишечнику) у щурів, а також в операційних матеріалах та сечі пацієнтів з раком грудної залози, легені та прямої кишки. Вміст ПА в біологічних матеріалах визначали методами тонкошарової хроматографії та високоефективної рідинної хроматографії, активність орнітиндекарбоксилази (ключового ферменту біосинтезу ПА) - радіометричним методом за продукцією ${ }^{14} \mathrm{CO}_{2}$ та/або шляхом хроматографічного визначення продукції путресцину. Для статистичної обробки даних застосовували t-критерій Стьюдента i, за потреби, точний метод Фішера. Результати і обговорення. Статистично значущі модуляції спектра ПА виявлені в процесі розвитку всіх досліджених пухлин. Виявлено, що патерни модуляцій значною мірою залежать від типу пухлини. Оскільки відображення спектра ПА на множину станів ферментативної рівноваги не є однозначним (будь-який патерн спектра може бути одержаний при двох або більше комбінаціях ферментативних активностей), реальна оптимізація протиполіамінної терапії потребує детальних ензимологічних досліджень. Висновок. Одержані результати демонструють значні і залежні від типу пухлини модуляції балансу ПА в процесі розвитку пухлин. Цей факт має спонукати до проведення спеціальних ензимологічних досліджень з метою оптимізації схем протипухлинної терапії із застосуванням модуляторів метаболізму ПА.
\end{abstract}

Ключові слова: поліаміни; метаболізм; протипухлинна терапія.

\section{ВстУП}

На сьогодні основні закономірності метаболізму поліамінів (ПА) у клітинах злоякісних пухлин і в організмі пацієнта описані у величезній кількості експериментальних, клінічних та оглядових робіт. Вже давно не підлягає сумніву той факт, що інгібітори різних ланок біосинтезу ПА здатні ефективно гальмувати ріст і прогресію злоякісних пухлин і завдяки цьому можуть бути дієвими засобами протипухлинної терапії [1, 2]. Доведено також, що визначення вмісту ПА в крові хворих та їх екскреції з сечею $є$ ефективним засобом моніторингу перебігу пухлинного процесу i, зокрема, методом контролю ефективності її лікування [1-4]. Тому може скластися враження, що основні питання в цій галузі вже вирішено.

Водночас нам не вдалося виявити публікації, присвячені закономірностям зміни спектра ПА (який є кінцевим проявом балансу різних ланок їх біосинтезу, інтерконверсії та катаболізму) у процесі росту та прогресії пухлин, особливо на клінічному матеріалі. Навіть у роботах співробітників нашого інституту, що містять найбільш повну інформацію із цього питання, такі дані розглядаються лише в аспекті доведення загальної тези щодо можливості застосування показників системи ПА як маркерів для діагностики та моніторингу пухлинного процесу [1-4]. Аналогічну спрямованість має і дисертація О.В. Балицької [5].

Тому метою цієї роботи стала відповідь на таке питання: чи існують особливості спектра ПА на різних стадіях розвитку пухлини, у тому числі при пухлинах різної локалізації та різних гістологічних типів? Для цього було проведено за даними кількох робіт [1, 6, 7] ретроспективний аналіз балансу окремих фракцій ПА у процесі хімічного канцерогенезу у щурів та на різних стадіях розвитку пухлини у пацієнтів онкологічних клінік.

\section{ОБ'ЄКТИ ТА МЕТОДИ ДОСЛІДЖЕННЯ}

У цьому дослідженні проведено ретроспективну оцінку (за даними кількох робіт $[1,6,7])$ змін балансу активності орнітиндекарбоксилази (ОДК), ключового ферменту біосинтезу ПА, та вмісту основних фракцій ПА - путресцину, спермідину та сперміну - у біоматеріалах щурів у процесі експериментального хімічного канцерогенезу та пацієнтів з пухлинами різних локалізацій на різних клінічних стадіях пухлинного процесу. Аналізували лише дані щодо солідних пухлин, оскільки у випадку асцитних новоутворень у тварин та онкогематологічних захворювань у тварин та людей, з огляду на певні причини (інші критерії стадій хвороби, інші закономірності проліферації та програмованої смерті пухлинних клітин тощо), співставлення даних з інформацією щодо солідних пухлин було б не завжди коректним.

Усі застосовані методи біохімічних та онкологічних досліджень детально описані в роботі [1].

Хоча не підлягає сумніву, що баланс різних фракцій ПА $є$ відображенням рівноваги відповідних ферментативних реакцій їх синтезу, інтерконверсії та катаболізму, такою ж мірою безсумнівно, що це відображення не є однозначним, тобто одне й те саме чисельне співвідношення вмісту різних фракцій ПА в біоматеріалі може бути сформоване при кількох різних співвідношеннях швидкості ферментативних реакцій. Тому в цій роботі ми утримувалися від будь-яких гіпотез стосовно ферментативної кінетики, залишивши їх розгляд для спеціального дослідження.

Для статистичної обробки даних застосовували t-критерій Стьюдента і, за необхідності, точний метод Фішера.

\section{РЕЗУЛЬТАТИ ТА ЇХ ОБГОВОРЕННЯ}

Експериментальний хімічний канцерогенез. У наведених нижче таблицях подані як абсолютні значення активності ОДК та вмісту ПА у відповідних біологічних об'єктах, так і співвідношення між ними, які характеризують відносну швидкість відповідних ферментативних перетворень. Таке викладення результатів забезпечує більш наочне уявлення про баланс ПА порівняно з наведенням лише абсолютних значень. Дані 
щодо абсолютних значень параметрів спектра ПА (у таблицях подані чорним кольором) відтворені за проаналізованими роботами $[1,6,7]$. Інформація щодо співвідношень між цими параметрами (у таблицях подані червоним кольором) обчислені самостійно на основі первинних протоколів досліджень, наданих доктором біологічних наук С.П. Залєток.

У табл. 1 та 2 показано зміни активності ОДК і вмісту путресцину, спермідину та сперміну в тканині печінки щурів на ранніх стадіях хімічного гепатоканцерогенезу (1-4 тиж введення канцерогена). Відповідні параметри сформованих гепатом наведені лише для порівняння - на таких термінах дослідження гепатоми ще відсутні.

Як показано в табл. 1 та 2, у цитозолі та ядерній фракції печінки щурів на 1-2-й тижні $\mathrm{N}$-нітрозодіетиламінгепатоканцерогенезу активність ОДК і вміст путресцину і спермідину значно підвищувалися порівнянні з інтактним контролем, що можна розцінити як захисно-компенсаторну реакцію на токсичну дію канцерогена і активація синтезу ПА, ймовірно, направлена на відновлення порушеної структури і функцій клітин, що розвинулися як наслідок токсичного пошкодження їх канцерогеном. 3 іншого боку, активація біосинтезу і накопичення в ранню стадію біологічно-активних ПА в таких клітинних структурах як ядра та плазматичні мембрани (щодо останніх результати не показані) може призводити до активізації різних сигнальних шляхів, залучених в експресію онкогенів, що беруть участь в ініціації неопластичного процесу.

Характерно, що для вмісту сперміну такі зміни були значно менш вираженими і виявлялися лише у ядерній фракції. Оскільки відомо, що спермін і інші ПА можуть посилювати зв'язування факторів транскрипції (наприклад нуклеарний фактор каппа В) з промоторними ділянками онкогенів [8], дані про збільшення в ядрах кількості клітин путресцину, спермідину і сперміну, хоч і опосередковано, можуть свідчити про залученість ПА в експресію онкогенів, які на ранній стадії канцерогенезу беруть участь в ініціації неопластичного процесу.

Надалі (3-4-й тижні) активність ОДК та вміст ПА поступово знижувалися, не досягаючи, однак, контрольного рівня (за винятком рівня сперміну, який був навіть дещо нижчим за контрольний). Варто зазначити, що профіль відносних швидкостей перетворень ОДК $\rightarrow$ путресцин, путресцин $\rightarrow$ спермідин і спермідин $\rightarrow$ спермін у печінці тварин уже 3 першого тижня гепатоканцерогенезу починає частково набувати рис, характерних для гепатоми.

Слід особливо відзначити, що абсолютні значення як активності ОДК, так і вмісту путресцину і спермідину залишалися весь час значно вищими за контрольні. Значно вищими від контрольних були також співвідношення путресцин/спермідин та спермідин/спермін. Водночас співвідношення ОДК/путресцин у більшості часових точок майже не відрізнялося від контрольного. У табл. 3 показані зміни тих самих параметрів метаболізму ПА на більш пізніх стадіях $\mathrm{N}$-нітрозодіетиламінгепатоканцерогенезу (1-6 міс, аж до виникнення гепатом).

Дані табл. 3 свідчать, що протягом 1-4-го місяців введення канцерогена все ще відбувалися певні компенсаторні реакції, що проявлялося у фазному характері змін параметрів. Однак уже через 5 міс дослідження профіль відносних швидкостей ферментативних перетворень став подібним такому в гепатомі, хоча абсолютні значення активності ОДК і вмісту ПА все ще були дещо нижчими порівняно з такими для гепатоми.

Зміни співвідношення ОДК/путресцин, путресцин/спермідин та спермідин/спермін на визначених термінах також носили фазний характер.

У табл. 4 показані зміни активності ОДК та вмісту ПА в слизовій оболонці тонкого кишечнику щурів у процесі канцерогенезу, індукованого 1,2-диметилгідразином.

Кінетичні характеристики метаболізму ПА та їх часові зміни в цій моделі хімічного канцерогенезу значно відрізнялися від попередніх. Так, активність ОДК виявилася

Таблиця 1. Активність ОДК (нмоль путресцину/мг білка за год) і вміст ПА (нмоль/мг білка) у цитозолі печінки щурів в ранній період $\mathrm{N}$-нітрозодіетиламін-гепатоканцерогенезу, M $\pm \mathrm{m}$

\begin{tabular}{|c|c|c|c|c|c|}
\hline \multirow[b]{2}{*}{ Об’єкт } & \multirow[b]{2}{*}{$\begin{array}{l}\text { Термін } \\
\text { (тиж) }\end{array}$} & \multirow[b]{2}{*}{$\begin{array}{l}\text { Активність ОДК } \\
\text { ОДК/путресцин }\end{array}$} & \multicolumn{3}{|c|}{ Вміст ПА } \\
\hline & & & $\begin{array}{c}\text { Путресцин } \\
\text { Путресцин/спермідин }\end{array}$ & $\begin{array}{c}\text { Спермідин } \\
\text { Спермідин/спермін }\end{array}$ & Спермін \\
\hline \multirow[t]{7}{*}{$\begin{array}{l}\text { Печінка тварин, що отри- } \\
\text { мували канцероген }\end{array}$} & 1 & $\begin{array}{c}1,10 \pm 0,20^{*} \\
0,34 \pm 0,08\end{array}$ & $\begin{array}{l}3,20 \pm 1,0^{*} \\
0,21 \pm 0,04\end{array}$ & $\begin{array}{c}15,60 \pm 0,50^{*} \\
4,73 \pm 0,57\end{array}$ & $3,30 \pm 0,70$ \\
\hline & 2 & $1,62 \pm 0,06^{*}$ & $4,65 \pm 1,26^{*}$ & $25,50 \pm 2,95^{*}$ & $2,00 \pm 0,63$ \\
\hline & & $0,35 \pm 0,06$ & $0,18 \pm 0,04$ & $12,75 \pm 2,81$ & \\
\hline & 3 & $1,48 \pm 0,11^{*}$ & $4,40 \pm 0,57^{\star}$ & $17,70 \pm 0,68^{*}$ & $1,93 \pm 0,01$ \\
\hline & & $0,34 \pm 0,03$ & $0,25 \pm 0,02$ & $9,17 \pm 0,28$ & \\
\hline & 4 & $0,95 \pm 0,08^{*}$ & $3,20 \pm 0,05^{\star}$ & $12,23 \pm 2,23^{*}$ & $1,57 \pm 0,11^{\star}$ \\
\hline & & $0,30 \pm 0,02$ & $0,26 \pm 0,03$ & $7,79 \pm 1,01$ & \\
\hline \multirow[t]{2}{*}{ Гепатома } & $22-26$ & $1,26 \pm 0,26^{*}$ & $5,26 \pm 0,84^{\star}$ & $13,25 \pm 0,39 *$ & $3,47 \pm 0,50$ \\
\hline & & $0,24 \pm 0,04$ & $0,40 \pm 0,04$ & $3,82 \pm 0,32$ & \\
\hline \multirow{2}{*}{\multicolumn{2}{|c|}{ Печінка контрольних тварин }} & $0,63 \pm 0,09$ & $1,6 \pm 0,15$ & $6,60 \pm 0,82$ & $2,20 \pm 0,30$ \\
\hline & & $0,39 \pm 0,05$ & $0,02 \pm 0,002$ & $3,00 \pm 0,39$ & \\
\hline
\end{tabular}

* $\mathrm{p}<0,05$ порівняно $з$ показниками у контрольних тварин, $\mathrm{n}=5-8$.

Таблиця 2. Активність ОДК (нмоль путресцину $/ 10^{9}$ ядер за год) і вміст ПА (нмоль $/ 10^{9}$ ядер) у ядерній фракції клітин печінки щурів в ранній період $\mathrm{N}$-нітрозодіетиламін-гепатоканцерогенезу та сформованих гепатом, $\mathrm{M} \pm \mathrm{m}$

\begin{tabular}{|c|c|c|c|c|c|}
\hline \multirow[b]{2}{*}{ Об'єкт } & \multirow{2}{*}{$\begin{array}{l}\text { Термін } \\
\text { (тиж) }\end{array}$} & \multirow{2}{*}{$\begin{array}{l}\text { Активність ОДК } \\
\text { ОДК/путресцин }\end{array}$} & \multicolumn{3}{|c|}{ Вміст ПА } \\
\hline & & & $\begin{array}{c}\text { Путресцин } \\
\text { Путресцин/спермідин }\end{array}$ & $\begin{array}{c}\text { Спермідин } \\
\text { Спермідин/спермін }\end{array}$ & Спермін \\
\hline Печінка & 1 & $3,30 \pm 0,44^{*}$ & $30,32 \pm 4,50^{*}$ & $29,00 \pm 4,89^{*}$ & $4,10 \pm 0,60^{*}$ \\
\hline \multirow{6}{*}{$\begin{array}{l}\text { тварин, що отримували } \\
\text { канцероген }\end{array}$} & & $0,11 \pm 0,02$ & $1,05 \pm 0,17$ & $7,07 \pm 1,13$ & \\
\hline & 2 & $\begin{array}{c}3,75 \pm 0,25^{\star} \\
0,12 \pm 0,01\end{array}$ & $\begin{array}{c}30,72 \pm 4,50^{*} \\
1,03 \pm 0,11\end{array}$ & $\begin{array}{c}29,80 \pm 1,67^{*} \\
4,81 \pm 0,86\end{array}$ & $6,20 \pm 1,80^{*}$ \\
\hline & 3 & $2,33 \pm 0,17^{\star}$ & $17,30 \pm 4,91^{*}$ & $20,00 \pm 3,21^{*}$ & $6,00 \pm 0,20^{*}$ \\
\hline & & $0,13 \pm 0,02$ & $0,87 \pm 0,19$ & $3,33 \pm 0,33$ & \\
\hline & 4 & $2,03 \pm 0,18^{*}$ & $19,30 \pm 2,37^{*}$ & $13,43 \pm 1,28^{*}$ & $4,37 \pm 0,82$ \\
\hline & & $0,11 \pm 0,01$ & $1,44 \pm 0,16$ & $3,07 \pm 0,46$ & \\
\hline \multirow[t]{2}{*}{ Гепатома } & $22-26$ & $4,32 \pm 1,14^{*}$ & $14,0 \pm 1,85^{\star}$ & $11,4 \pm 1,43^{\star}$ & $2,41 \pm 0,61$ \\
\hline & & $0,31 \pm 0,06$ & $1,23 \pm 0,16$ & $4,73 \pm 0,90$ & \\
\hline \multirow[t]{2}{*}{ Печінка контрольних тварин } & & $0,30 \pm 0,18$ & $2,80 \pm 0,40$ & $5,60 \pm 0,25$ & $2,80 \pm 0,34$ \\
\hline & & $0,11 \pm 0,04$ & $0,50 \pm 0,05$ & $2,00 \pm 0,16$ & \\
\hline
\end{tabular}

* $\mathrm{p}<0,05$ порівняно $з$ показниками у контрольних тварин, $\mathrm{n}=5-8$. 
Таблиця 3. Активність ОДК (нмоль путресцину/мг білка за год) і вміст ПА (нмоль/мг білка) в цитозольній фракції клітин печінки щурів у процесі

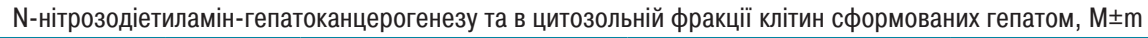

\begin{tabular}{|c|c|c|c|c|c|}
\hline \multirow[b]{2}{*}{ Об'єкт } & \multirow[b]{2}{*}{$\begin{array}{l}\text { Термін } \\
\text { (міс) }\end{array}$} & \multirow{2}{*}{$\begin{array}{l}\text { Активність ОДК } \\
\text { ОДК/путресцин }\end{array}$} & \multicolumn{3}{|c|}{ Вміст ПА } \\
\hline & & & $\begin{array}{c}\text { Путресцин } \\
\text { Путресцин/спермідин }\end{array}$ & $\begin{array}{c}\text { Спермідин } \\
\text { Спермідин/спермін }\end{array}$ & Спермін \\
\hline Печінка тварин, що отри- & 1 & $0,95 \pm 0,08^{*}$ & $3,20 \pm 0,50^{*}$ & $12,23 \pm 2,23^{*}$ & $1,57 \pm 0,11^{*}$ \\
\hline \multirow[t]{8}{*}{ мували канцероген } & & $0,30 \pm 0,04$ & $0,26 \pm 0,04$ & $7,79 \pm 0,10$ & \\
\hline & 2 & $0,48 \pm 0,05$ & $1,80 \pm 0,50$ & $8,60 \pm 0,45$ & $2,80 \pm 0,26$ \\
\hline & & $0,27 \pm 0,05$ & $0,21 \pm 0,03$ & $3,07 \pm 0,20$ & \\
\hline & 3 & $0,52 \pm 0,03$ & $1,90 \pm 0,45$ & $8,90 \pm 0,50$ & $2,95 \pm 0,32$ \\
\hline & & $0,27 \pm 0,04$ & $0,21 \pm 0,03$ & $3,02 \pm 0,26$ & \\
\hline & & $0,45 \pm 0,05$ & $0,17 \pm 0,02$ & $4,42 \pm 0,33$ & \\
\hline & 5 & $0,98 \pm 0,08^{*}$ & $4,30 \pm 0,30^{*}$ & $12,20 \pm 0,25^{\star}$ & $2,80 \pm 0,32$ \\
\hline & & $0,23 \pm 0,02$ & $0,35 \pm 0,02$ & $4,36 \pm 0,28$ & \\
\hline \multirow[t]{2}{*}{ Гепатома } & 6 & $1,26 \pm 0,26^{*}$ & $5,26 \pm 0,84^{\star}$ & $13,25 \pm 0,39^{*}$ & $3,47 \pm 0,50$ \\
\hline & & $0,24 \pm 0,04$ & $0,40 \pm 0,04$ & $3,82 \pm 0,32$ & \\
\hline \multirow{2}{*}{\multicolumn{2}{|c|}{ Печінка контрольних тварин }} & $0,63 \pm 0,09$ & $1,60 \pm 0,15$ & $6,60 \pm 0,82$ & $2,20 \pm 0,30$ \\
\hline & & $0,39 \pm 0,04$ & $0,24 \pm 0,03$ & $3,00 \pm 0,39$ & \\
\hline
\end{tabular}

${ }^{*} \mathrm{p}<0,05$ порівняно з показниками у контрольних тварин, $\mathrm{n}=5-8$.

Таблиця 4. Активність ОДК (пмоль ${ }^{14} \mathrm{CO}_{2} /$ мг білка за годину) та вміст ПА (нмоль/мг білка) в слизовій оболонці тонкого кишечнику щурів у процесі канцерогенезу, індукованого 1,2-диметилгідразином, $\mathrm{M} \pm \mathrm{m}$

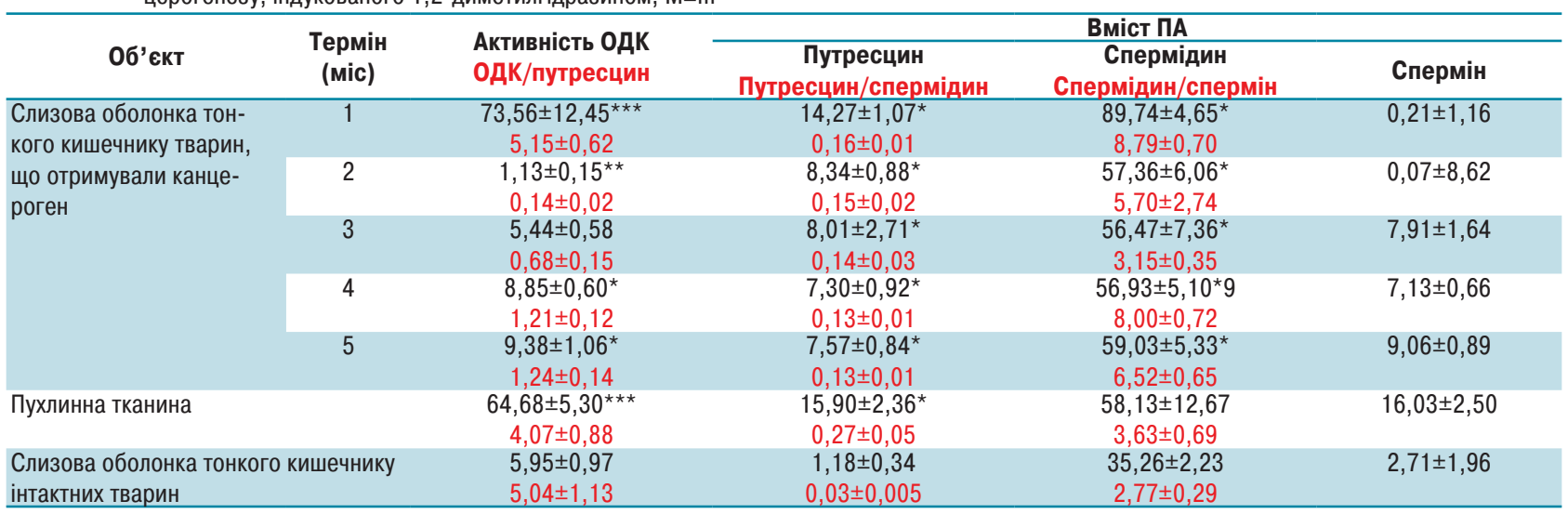

${ }^{*} \mathrm{p}<0,05$ порівняно з показниками у контрольних тварин, $n=5-8 ;{ }^{* *} p<0,01$ порівняно з показниками у контрольних тварин, $n=5-8 ;$ *** $p<0,001$ порівняно 3 показниками у контрольних тварин, $\mathrm{n}=5-8$.

підвищеною в 12 разів порівняно з контролем через 1 міс після початку введення канцерогена. Однак уже через 2 міс дослідження вона стрибкоподібно знизилася і виявилася навіть більш ніж у 5 разів нижчою за контрольну. Протягом 3-5-го місяців спостереження активність ОДК повільно підвищувалася i, нарешті, при малігнізації зросла стрибкоподібно, ставши у сформованих пухлинах в 11 разів вищою за контрольну, тобто майже рівною тій, що спостерігалася через 1 міс дослідження.

Вміст путресцину в слизовій оболонці весь час зберігався на рівні, в 4-5 разів вищому порівняно 3 контролем, а в пухлинній тканині досяг 9-разового перевищення рівня контролем. Вміст спермідину після 2,5-разового підвишення наприкінці першого місяця, надалі, у тому числі і в пухлинній тканині, утримувався на рівні приблизно 1,6-кратного перевищення порівняно 3 контролем. Нарешті, вміст сперміну на жодному терміні дослідження не мав статистично значущих відмінностей від контролю.

Співвідношення ОДК/путресцин через 2 міс спостереження стрибкоподібно знизилося до рівня, у 36 разів нижчого порівняно з контролем, надалі ж поступово підвищувалося, досягши у пухлинній тканині майже контрольного рівня. Співвідношення путресцин/спермідин протягом усього дослідження утримувалося на рівні 4-5-кратного перевищення порівняно з контролем, залишившись на тому ж рівні і в пухлинній тканині. Співвідношення спермідин/спермін через 1 міс спостереження виявилося втричі вищим від контрольного, надалі ж коливалося в межах 1,1-2,8-разового перевищення рівня контролю, зупинившись у пухлинній тканині на рівні 1,3-разового перевищення. Особливо відзначимо, що, на відміну від гепатоканцерогенезу, навіть через 5 міс до- слідження профіль відносних швидкостей ферментативних перетворень не став подібним до такого в пухлинній тканині, що проявилося у відмінностях між ними за співвідношеннями ОДК/путресцин та спермідин/спермін.

У табл. 5 показані зміни активності ОДК та вмісту ПА в слизовій оболонці товстого кишечнику щурів у процесі канцерогенезу, індукованого тим самим канцерогеном.

Динаміка активності ОДК в слизовій оболонці була подібною до такої для тонкого кишечнику. Вміст путресцину, як і у випадку з тонким кишечником, зберігався весь час дещо вищим порівняно з контрольним, однак, на відміну від тонкого кишечнику, не у 4-5 разів, а лише у 1,05-2 рази для слизової оболонки та у 2,3 раза для пухлинної тканини. Вміст спермідину змінювався у якісному відношенні подібно до такого у тонкому кишечнику, однак, на відміну від останнього, на жодному терміні дослідження ці зміни не були статистично значущими. Нарешті, динаміка вмісту спермідину відрізнялася від такої у тонкому кишечнику принциповим чином: через 5 міс дослідження рівень спермідину в слизовій оболонці виявився у 2,3 раза (статистично достовірно) нижчим, а в пухлинній тканині - у 7,8 раза вищим порівняно 3 контрольним.

Якісні відмінності як окремої динаміки співвідношень ОДК/путресцин, путресцин/спермідин та спермідин/спермін, так і профілів відносних швидкостей ферментативних перетворень при канцерогенезі товстого кишечнику від таких при канцерогенезі тонкого кишечнику і гепатоканцерогенезі очевидні і на даному рівні дослідження не потребують спеціальних коментарів. Відзначимо лише, шо, подібно до гепатоканцерогенезу і на відміну від канцерогенезу тонкого кишечнику, через 5 міс дослідження профіль відносних 
Таблиця 5. Активність ОДК (пмоль ${ }^{14} \mathrm{CO}_{2} /$ мг білка за год) та вміст ПА (нмоль/мг білка) в слизовій оболонці товстого кишечнику щурів у процесі канцерогенезу, індукованого 1,2-диметилгідразином, М $\pm m$

\begin{tabular}{|c|c|c|c|c|c|}
\hline \multirow[b]{2}{*}{ Об'єКт } & \multirow[b]{2}{*}{$\begin{array}{l}\text { Термін } \\
\text { (міс) }\end{array}$} & \multirow[b]{2}{*}{$\begin{array}{l}\text { Активність ОДК } \\
\text { ОДК/путресцин }\end{array}$} & \multicolumn{3}{|c|}{ Вміст ПА } \\
\hline & & & $\begin{array}{c}\text { Путресцин } \\
\text { Путресцин/спермідин }\end{array}$ & $\begin{array}{c}\text { Спермідин } \\
\text { Спермідин/спермін }\end{array}$ & Спермін \\
\hline Слизова оболонка тов- & 1 & $41,04 \pm 6,78^{*}$ & $10,60 \pm 1,93^{\star}$ & $41,51 \pm 3,79$ & $10,05 \pm 1,21$ \\
\hline стого кишечнику тва- & & $3,87 \pm 0,68$ & $0,26 \pm 0,04$ & $4,13 \pm 0,43$ & \\
\hline \multirow{8}{*}{$\begin{array}{l}\text { рин, що отримували кан- } \\
\text { цероген }\end{array}$} & 2 & $1,04 \pm 0,15^{\star}$ & $6,85 \pm 0,68$ & $23,38 \pm 2,75$ & $6,64 \pm 1,36^{*}$ \\
\hline & & $0,15 \pm 0,02$ & $0,29 \pm 0,03$ & $3,52 \pm 0,56$ & \\
\hline & 3 & $12,15 \pm 2,43^{\star}$ & $8,60 \pm 2,13$ & $26,27 \pm 5,50$ & $13,60 \pm 2,02$ \\
\hline & & $1,41 \pm 0,32$ & $0,33 \pm 0,08$ & $1,93 \pm 0,35$ & \\
\hline & 4 & $16,21 \pm 0,88^{\star}$ & $5,65 \pm 1,86$ & $30,29 \pm 6,48$ & $5,55 \pm 0,72^{*}$ \\
\hline & & $2,87 \pm 0,55$ & $0,19 \pm 0,05$ & $5,46 \pm 0,93$ & \\
\hline & 5 & $25,68 \pm 6,96^{\star}$ & $10,43 \pm 1,29^{*}$ & $24,28 \pm 1,60$ & $9,83 \pm 0,92$ \\
\hline & & $2,46 \pm 0,46$ & $0,43 \pm 0,04$ & $2,46 \pm 0,02$ & \\
\hline \multirow{2}{*}{\multicolumn{2}{|c|}{ Пухлинна тканина }} & $65,81 \pm 6,76^{\star}$ & $12,39 \pm 1,28 *$ & $46,22 \pm 6,47$ & $12,54 \pm 1,00$ \\
\hline & & $5,31 \pm 0,53$ & $0,27 \pm 0,03$ & $3,69 \pm 0,41$ & \\
\hline \multicolumn{2}{|c|}{ Слизова оболонка товстого кишечнику } & $3,91 \pm 0,47$ & $5,38 \pm 2,02$ & $28,59 \pm 7,27$ & $12,71 \pm 1,96$ \\
\hline \multicolumn{2}{|l|}{ контрольних тварин } & $0,73 \pm 0,15$ & $0,19 \pm 0,06$ & $2,25 \pm 0,45$ & \\
\hline
\end{tabular}

${ }^{*} \mathrm{p}<0,05$ порівняно з показниками у контрольних тварин, $\mathrm{n}=5-8$.

Таблиця 6. Активність ОДК (пмоль путресцину/мг білка за год) і вміст ПА (нмоль/мг білка) у макроскопічно незміненій тканині (а), тканині, прилеглій

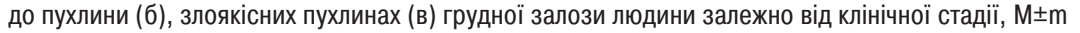

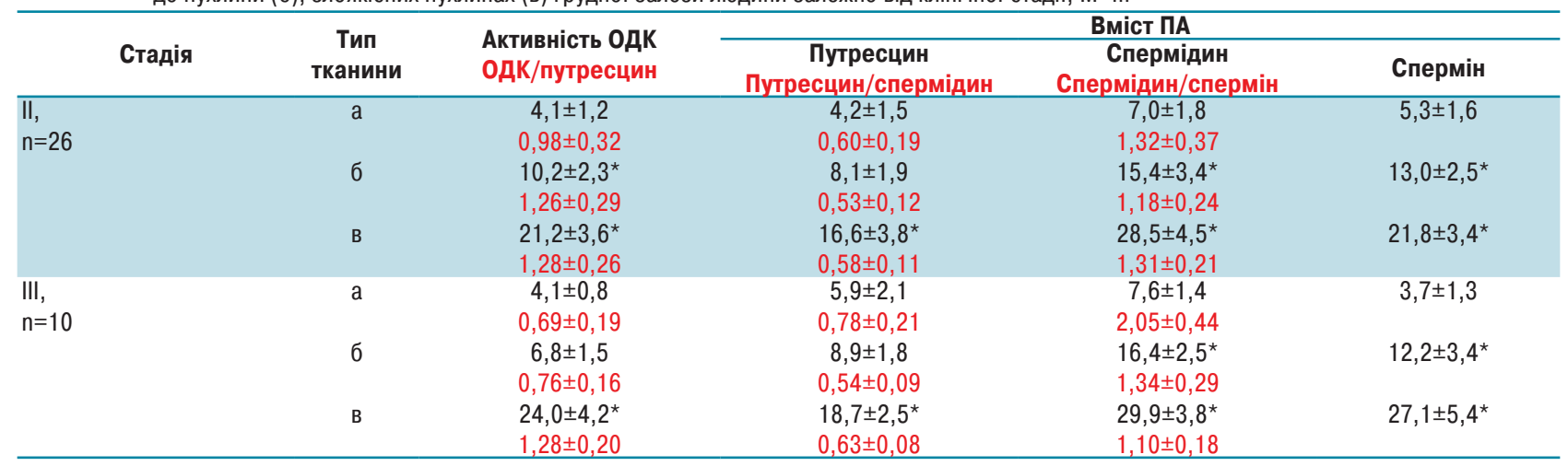

* $p<0,01$ порівняно 3 макроскопічно незміненою тканиною, n=5-8.

швидкостей ферментативних перетворень у слизовій оболонці став подібним до такого в пухлинній тканині.

Клінічні дослідження. Ретроспективний аналіз клінічних даних, порівняно з проведеним вище аналізом даних щодо експериментального хімічного канцерогенезу, має дві особливості, які не дозволяють проводити пряме співставлення цих груп даних.

По-перше, це неможливість інтактного контролю при дослідженні операційного матеріалу. 3 цієї причини, біохімічні дані щодо пухлинної тканини зазвичай співставляють з даними щодо макроскопічно незміненої тканини ураженого органа та тканини, безпосередньо прилеглої до пухлини. 3 огляду ж на давно доведений лабораторією Шапота [9] та іншими дослідниками факт «біохімічного уподібнення» умовно здорової тканини до пухлинної в процесі розвитку пухлинного процесу, це зовсім не те саме, що співставлення з інтактним контролем.

По-друге, головним завданням клінічних досліджень нашого відділу була розробка неінвазивного методу моніторингу перебігу пухлинного процесу та визначення успішності лікування, тому основна увага приділялася дослідженню екскреції ПА $з$ сечею.

Однак, попри такі ускладнення, з ретроспективного аналізу клінічних даних нашого відділу можна зробити певні висновки в аспекті мети цієї роботи.

У табл. 6 і 7 представлені дані щодо активності ОДК і вмісту ПА у макроскопічно незміненій тканині (a), тканині, прилеглій до пухлини (б), злоякісних пухлинах (в) грудної залози людини (див. табл. 6) і щодо екскреції ПА з сечею у хворих на рак грудної залози (див. табл. 7) залежно від клінічної стадії захворювання.

В аспекті цього дослідження, в табл. 6 звертають на себе увагу такі факти:
Таблиця 7. Екскреція ПА з сечею (мг/добу) у хворих на рак грудної залози залежно від стадії захворювання, $\mathrm{M} \pm \mathrm{m}$

\begin{tabular}{lcccc}
\hline $\begin{array}{c}\text { Діагноз } \\
\text { та стадія }\end{array}$ & $\mathbf{N}$ & $\begin{array}{c}\text { Путресцин } \\
\text { Путресцин/ } \\
\text { спермідин }\end{array}$ & $\begin{array}{c}\text { Спермідин } \\
\text { Спермідин/спермін }\end{array}$ & Спермін \\
\hline Доброякісні & 40 & $2,62 \pm 0,76$ & $3,95 \pm 0,41$ & $1,96 \pm 0,37$ \\
пухлини & & $0,66 \pm 0,13$ & $2,02 \pm 0,29$ & \\
I & 30 & $5,34 \pm 0,76^{*}$ & $6,42 \pm 0,86^{\star}$ & $2,25 \pm 0,51$ \\
& & $0,83 \pm 0,11$ & $2,85 \pm 0,51$ & \\
II & \multirow{2}{*}{34} & $5,43 \pm 0,78^{\star}$ & $9,82 \pm 1,16^{\star}$ & $4,19 \pm 0,88^{\star}$ \\
& & $0,55 \pm 0,07$ & $2,34 \pm 0,39$ & \\
III & 54 & $8,26 \pm 0,78^{\star}$ & $12,53 \pm 1,75^{\star}$ & $4,95 \pm 0,79^{\star}$ \\
& & $0,66 \pm 0,08$ & $2,53 \pm 0,38$ & \\
\hline
\end{tabular}

${ }^{*} \mathrm{p}<0,05$ порівняно 3 доброякісними пухлинами.

a) як на II, так і на III стадії захворювання активність ОДК і вміст кожної з досліджених фракцій ПА в пухлинній тканині підвищувалися в напрямку $(\mathrm{a} \rightarrow \sigma \rightarrow \mathrm{B})$;

б) водночас на II стадії тканини типів а, б, в не мали між собою достовірних відмінностей за співвідношеннями ОДК/путресцин, путресцин/спермідин та спермідин/спермін, тоді як на III стадії підвищувалося співвідношення ОДК/путресцин у пухлинній тканині порівняно з макроскопічно незміненою (а) та прилеглою до пухлини тканинами (б), а співвідношення спермідин/спермін прогресивно знижувалося в напрямку $(\mathrm{a} \rightarrow \sigma \rightarrow \mathrm{B})$.

Екскреція ж ПА з сечею демонструє дещо іншу картину. Тут, при монотонному зростанні абсолютних показників екскреції в напрямку від доброякісних пухлин до III стадії розвитку пухлини має місце достовірне зниження співвідношення путресцин/спермідин на II стадії порівняно з I, зі збереженням тієї ж тенденції на III стадії. Співвідношення ж спермідин/спермін при цьому залишається практично незмінним. Така різниця між показниками операційного 
матеріалу та сечі може вказувати на існування диференційних патофізіологічних змін ниркової фільтрації щодо різних фракцій ПА в процесі розвитку пухлини.

У табл. 8 наведено дані щодо екскреції ПА з сечею у хворих на рак легені.

Щодо абсолютних показників, звертає на себе увагу значно менша, ніж при раку грудної залози, вираженість тенденції до підвищення екскреції путресцину та спермідину від III до IV стадії захворювання i, окрім того, наявність тенденції до зниження екскреції сперміну. Що ж до співвідношень путресцин/спермідин та спермідин/спермін, можна відзначити досить сильну тенденцію до зниження співвідношення спермідин/спермін у сечі хворих з I-II стадією захворювання порівняно як з умовним контролем (групою пацієнтів 3 пневмонією та хронічним обструктивним бронхітом), так і з хворими з III-IV стадією раку легені.

У хворих на рак прямої кишки (табл. 9) динаміка екскреції ПАзалежно від стадії захворювання виявилася принципово іншою.

Тут з розвитком хвороби було пов'язане достовірне (відносно I стадії, але не між II-IV стадіями) підвищення експресії лише сперміну при практично незмінних рівнях екскреції путресцину та спермідину. Водночас спостерігалася сильна за t-критерієм Стьюдента і достовірна за точним методом Фішера $(\mathrm{p}=0,05)$ тенденція до зниження співвідношення путресцин/спермідин і протилежна (з тими ж рівнями достовірності) тенденція для спермідину/сперміну.

\section{ВИСНОВКИ}

Наведені дані дають змогу сформулювати 3 висновки, що дають позитивну відповідь на питання, сформульоване в меті дослідження.

1. Як у процесі експериментального канцерогенезу, так і в процесі розвитку пухлин різних локалізацій у пацієнтів дійсно можуть відбуватися статистично достовірні зміни балансу ПА.

2. Профіль таких змін може істотно відрізнятися як при різних видах експериментального канцерогенезу, так і в разі розвитку пухлин різних локалізацій.

3. Ензимологічна природа змін балансу ПА в процесі розвитку пухлин потребує спеціальних досліджень, конкретизованих за локалізаціями та гістологічними типами пухлин,

Таблиця 8. Екскреція ПА з сечею (мг/добу) у хворих на рак легені залежно від стадії захворювання, $\mathrm{M} \pm \mathrm{m}$

\begin{tabular}{|c|c|c|c|c|}
\hline $\begin{array}{c}\text { Діагноз } \\
\text { та стадія }\end{array}$ & $\mathbf{N}$ & $\begin{array}{l}\text { Путресцин } \\
\text { Путресцин/ } \\
\text { спермідин }\end{array}$ & $\begin{array}{c}\text { Спермідин } \\
\text { Спермідин/ } \\
\text { спермін }\end{array}$ & Спермін \\
\hline Пневмонія & 29 & $2,84 \pm 1,03$ & $4,13 \pm 0,31$ & $1,37 \pm 0,31$ \\
\hline $\begin{array}{l}\text { та хронічний } \\
\text { обструктив- } \\
\text { ний бронхіт }\end{array}$ & & $0,69 \pm 0,15$ & $3,01 \pm 0,47$ & \\
\hline$|-| \mid$ & 12 & $\begin{array}{c}7,09 \pm 1,74^{*} \\
0,82 \pm 0,17\end{array}$ & $\begin{array}{c}8,62 \pm 1,44^{*} \\
1,85 \pm 0,49\end{array}$ & $4,65 \pm 1,68^{*}$ \\
\hline III & 63 & $\begin{array}{c}6,06 \pm 0,62^{*} \\
0,56 \pm 0,06\end{array}$ & $\begin{array}{c}10,75 \pm 1,06^{*} \\
3,77 \pm 0,68\end{array}$ & $2,85 \pm 0,74^{*}$ \\
\hline IV & 27 & $\begin{array}{c}8,91 \pm 1,42^{*} \\
0,86 \pm 0,13\end{array}$ & $\begin{array}{c}10,35 \pm 1,47^{*} \\
3,79 \pm 1,14\end{array}$ & $2,73 \pm 1,25^{\star}$ \\
\hline
\end{tabular}

* $p<0,05$ порівняно 3 пневмонією та обструктивним бронхітом.

Таблиця 9. Екскреція ПА з сечею (мг/добу) у хворих на рак прямої кишки залежно від стадії захворювання, $\mathrm{M} \pm \mathrm{m}$

\begin{tabular}{|c|c|c|c|c|}
\hline $\begin{array}{c}\text { Діагноз } \\
\text { та стадія }\end{array}$ & $\mathbf{N}$ & $\begin{array}{c}\text { Путресцин } \\
\text { Путресцин/ } \\
\text { спермідин }\end{array}$ & $\begin{array}{c}\text { Спермідин } \\
\text { Спермідин/ } \\
\text { спермін }\end{array}$ & Спермін \\
\hline I & 7 & $\begin{array}{l}8,02 \pm 1,30 \\
1,47 \pm 0,29\end{array}$ & $\begin{array}{l}5,44 \pm 1,29 \\
1,39 \pm 0,67\end{array}$ & $0,39 \pm 0,28$ \\
\hline II & 7 & $\begin{array}{l}7,87 \pm 1,14 \\
1,24 \pm 0,25\end{array}$ & $\begin{array}{l}6,37 \pm 1,75 \\
2,39 \pm 1,16\end{array}$ & $2,67 \pm 1,88$ \\
\hline III & 85 & $\begin{array}{l}6,63 \pm 0,47 \\
0,98 \pm 0,07\end{array}$ & $\begin{array}{l}5,91 \pm 0,41 \\
2,71 \pm 0,26\end{array}$ & $2,18 \pm 0,26^{*}$ \\
\hline IV & 36 & $\begin{array}{l}6,46 \pm 1,09 \\
0,96 \pm 0,16\end{array}$ & $\begin{array}{l}6,76 \pm 1,08 \\
3,98 \pm 0,76\end{array}$ & $1,70 \pm 0,38 *$ \\
\hline
\end{tabular}

* $\mathrm{p}<0,05$ порівняно 3 I стадією хвороби.
3 метою оптимізації схем лікування онкологічних хворих модуляторами метаболізму ПА.

Подяка. Автор висловлює щиру подяку доктору біологічних наук С.П. Залєток за люб’язний дозвіл використати дані їі робіт для проведення додаткового аналізу та за плідне обговорення матеріалу статті.

\section{СПИСОК ВИКОРИСТАНОЇ ЛІТЕРАТУРИ}

1. Залєток, С. П. (2007). Поліаміни - маркери злоякісного росту і мішень для протипухлинної терапії (Дис. д-ра мед. наук). Інститут експериментальної патології, онкології і радіобіології ім. Р.Є. Кавецького НАН України, Київ.

2. Залєток, С. П. (2010). Роль поліамінів в канцерогенезі та в пухлинному рості: Онкологія. Вибрані лекції для студентів і лікарів. Київ: Здоров'я України.

3. Бердинских, Н. К., Залеток, С. П., Зиневич, А. К., \& Евтушенко, А. В. (1980). Определение экскреции полиаминов в диагностике злокачественных опухолей идля оценки лечения онкологических больных: Методические рекомендации. Киев.

4. Залєток, С. П., Шляховенко, В. О., Стаховський, Е. О., Кленов, О. О., Бентрад, В. В., Гоголь, С. В., ...Карнаушенко, О. В. (2018). Поліаміни та рибонуклеази як маркери для диференційної діагностики та прогнозу перебігу раку простати: Методичні рекомендації. Київ.

5. Балицкая, О.В. (1992). Полиамины и некоторые ферменты их обмена при нефробластоме и злокачественных лимфомах у детей (Дис. канд. мед. наук). Институт экспериментальной патологии, онкологии и радиобиологии им. Р. . Кавецкого НАН Украины. Киев.

6. Бердинских, Н. К., \& Залеток, С. П. (1987). Полиамины и опухолевый рост. Киев: Наукова думка.

7. Залєток, С. П., Бердинських, Н. К., Тарутінов, В. І., Скляр, С. Ю., Лялюшко, Н. М., \& Александрова, Н. О. (2000). Дослідження показників метаболізму поліамінів в пухлинах та фізіологічних рідинах у хворих з новоутвореннями молочної залози. Онкологія, 2(4), 250-252.

8. Zaletok, S., Aleksandrova, N., Berdynskykh, N., Ignatenko, N., Gogol, S., Orlovsky, A., ...Chekhun, V. (2004). Role of polyamines in the function of nuclear transcription factor NF-kB in breast cancer cells. Экспериментальная онкология, 26(3), 221-225

9. Шапот, В. С. (1975). Биохимические аспекты опухолевого роста. Москва: Медицина.

\section{Изменения баланса полиаминов в процессе развития опухолевого процесса в эксперименте} и клинике

\section{А.А. Орловский}

Институт экспериментальной патологии, онкологии и радиобиологии им. Р.E. Кавецкого НАН Украины, Киев

Резюме. Введение. Ингибиторы ферментов биосинтеза и интерконверсии полиаминов (ПА) известны как одна из групп эффективных противоопухолевых средств. Однако реальные условия равновесия ферментативных реакций в системе метаболизма ПА в процессе развития опухолей на сегодня недостаточно изучены. Конечным проявлением этого ферментативного баланса выступает паттерн спектра ПА в опухолевой ткани и в биологических жидкостях организма. Цель исследования. Сравнить вариабельность паттернов спектра ПА в процессе развития опухолей разной этиологии и локализации в эксперименте и клинике. Методы исследования. Паттерны спектра ПА исследовали в процессе 3 видов экспериментального химического канцерогенеза (N-нитрозодиэтиламинового гепатоканцерогенеза; 1,2-диметилгидразинового канцерогенеза толстого и тонкого кишечника) у крыс, а также в операционных материалах и моче пациентов с раком грудной железы, тонкой и прямой кишки. Содержание ПА в биологических материалах определяли методами тонкослойной хроматографии и высокоэффективной жидкостной хроматографии, активность орнитиндекарбоксилазы (ключевого фермента биосинтеза ПА) - радиометрическим методом по продукции ${ }^{14} \mathrm{CO}_{2}$ и/или путем хроматографического определения продукции путресцина. Для статистической обработки данных использовали t-критерий Стьюдента и, при необходимости, точный метод Фишера. Результаты и обсуждение. Статистически значимые модуляции спектра ПА выявлены в процессе развития всех исследованных опухолей. Показано, что паттерны модуляций существенно зависят от типа опухоли. Поскольку отображение спектра ПА на множество состояний ферментативного равновесия неоднозначно (любой паттерн спектра может быть получен при двух или более комбинациях ферментативных активностей), реальная оптимизация противополиаминной терапии требует детальных энзимологических исследований. Заключение. Полученные результаты 


\section{Оригінальні статті / Original Articles}

демонстрируют значительные и зависимые от типа опухоли модуляции баланса ПА в процессе развития опухолей. Этот факт может служить побудительным мотивом для проведения специальных энзимологических исследований с целью оптимизации схем противоопухолевой терапии с применением модуляторов метаболизма ПА.

Ключевые слова: полиамины, метаболизм, противоопухолевая терапия.

\section{Variability of polyamine metabolic balance during experimental and human tumor development \\ O.A. Orlovsky \\ R.E. Kavetsky Institute of Experimental Pathology, Oncology and Radiobiology, NAS of Ukraine, Kyiv}

Summary. Introduction. Inhibitors of the enzymes of the polyamine (PA) biosynthesis and back-conversion are known as a kind of the effective anticancer remedies. But real conditions of the enzymatic reaction balance variability in the PA metabolic system during the tumor development are still studied insufficiently. The end expression of this enzymatic balance is a pattern of the PA spectrum in the tumor tissue and in the biological fluids of the tumor-bearing organism. Aim of research. To compare the PA spectrum patterns variability during experimental and clinical tumor development of different aetiology and location. Methods of research. PA spectrum patterns were studied during three kinds of experimental chemical carcinogenesis ( $\mathrm{N}$-nitrosodiethylamine liver carcinogenesis; 1,2-dimethyl hydrazine large and small intestine carcinogenesis) in rats as well as in the operational materials and urine of the patients with mammary, lung and rectal cancer. PA content in the biological materials was measured by the methods of thin-layer chromatography and high performance liquid chromatography, ornithine decarboxylase (the key enzyme of the PA biosynthesis) activity - by radiometric determination of ${ }^{14} \mathrm{CO}_{2}$ production and/or chromatographic determination of putrescine production. Student's t-criterion and, in need, Fisher's exact method were used for statistical data treatment. Results and Discussion. Statistically significant modulations of PA spectrum were discovered during all kinds of tumor development have been studied. The modulation patterns were found to be significantly different dependently on the kind of tumor. Because of ambiguity of the PA spectrum mapping into the set of the enzymic balance stages (each pattern of PA spectrum may be obtained in two or more combinations of the enzyme activities), real optimization of the «antipolyamine» therapy require detailed enzymological investigations. Conclusion. Our resuts demonstrate significant and tumor-kind-dependent modulations of the PA balance during tumor development. This fact has to promote special enzymological investigations having a goal to optimize anticancer therapeutic schemes including the PA metabolism modulators.

Key words: polyamine, metabolism, anticancer therapeutic.

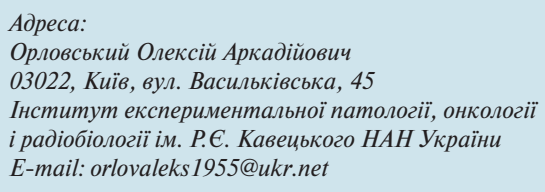

